\title{
"O CINEMA FALADO É O GRANDE CULPADO DA TRANSFORMAÇÃO": a chegada do cinema sonoro em Pernambuco (1930)
}

\author{
Arthur Gustavo Lira do Nascimento*
}

\begin{abstract}
RESUMO: Com a chegada do cinema sonoro norte-americano às salas de cinema recifenses, a cinematografia local, ainda produzindo filmes silenciosos, perde seu espaço. O cinema mudo pernambucano foi então ofuscado pelas inovações técnicas e dificuldades financeiras. Visto as inúmeras reivindicações dos cineastas brasileiros, o governo de Getúlio Vargas, iniciado em 1930, vai buscar incentivar o cinema nacional através de leis e financiamentos voltados às produções brasileiras. No Recife, os cineastas locais encontraram nos curtas-metragens, documentários e filmes propagandísticos uma possibilidade de fazer cinema. Este artigo tem por finalidade discutir a chegada do cinema sonoro em Pernambuco e as transformações ocasionadas por este processo.
\end{abstract}

PALAVRAS-CHAVE: História; Cinema; Cinema Sonoro; Pernambuco.

\section{"The talkies is the great guilty of transformation": the arrival of the sound films in Pernambuco (1930)}

\begin{abstract}
With the arrival of American talkies to Recife, the local cinematography, still producing silent films, loses its space. The silent movies of Pernambuco was then overshadowed by technical innovations and financial difficulties. Because of the numerous claims of Brazilian filmmakers, the government of Getúlio Vargas, begun in 1930, seeks to encourage national cinema through laws and funding directed to the Brazilian productions. In Recife, the local filmmakers found in short films, documentaries and propaganda films a possibility to make movies. This article aims to discuss the arrival of sound films in Pernambuco and the transformations caused by this process.
\end{abstract}

KEYWORDS: History; Cinema; Sound films; Pernambuco.

\section{"El cine hablado es el gran culpable de la transformación": la llegada del cine sonoro a Pernambuco (1930)}

RESUMEN: Con la llegada del cine sonoro norteamericano a los cines de Recife, la cinematografía local, todavía produciendo películas silenciosas, pierdió su espacio. El cine silencioso de Pernambuco fue entonces ofuscado por las innovaciones técnicas y dificultades financieras. Con las numerosas reclamaciones de los cineastas brasileños, el gobierno de Getúlio Vargas, iniciado en 1930, buscó incentivar el cine nacional a través de leyes y financiamientos dirigidos a las producciones brasileñas. En Recife, los cineastas locales encontraron en los cortometrajes, documentales y películas propagandísticas una posibilidad de hacer cine. Este artículo tiene por finalidad discutir la llegada del cine sonoro a Pernambuco y las transformaciones ocasionadas por este proceso.

PALABRAS CLAVE: Historia; Cine; Cine Sonoro; Pernambuco.

\footnotetext{
*Doutorando e Mestre pelo Programa de Pós-graduação em História da Universidade Federal de Pernambuco (UFPE). Bolsista da Coordenação de Aperfeiçoamento de Pessoal de Nível Superior pela Coordenação de Aperfeiçoamento de Pessoal de Nível Superior (CAPES). Contato: Av. da Arquitetura, s/n CFCH- $10^{\circ} \mathrm{Andar}$, CDU, CEP: 50740-550, Recife-PE, Brasil. E-mail: arthurlira31 @gmail.com.
} 
- Francamente, estou surpreso. Pois então você, um rapaz tão moço a seguir ideias tão velhas?! Você não gosta de cinema?!...

- Que quer, meu amigo? Eu sou assim. Não é meu costume acompanhar as multidões...

- Mas não se trata de acompanhar as multidões. Trata-se apenas de ser inteligente, de possuir essa coisinha sutil que se chama espírito moderno.

- Espírito moderno! Ora espírito moderno! Então é espírito moderno combater, destruir as belezas mais puras? Abandonar a fina espiritualidade do teatro pela sua "popularização" mercantilizada?

- Em primeiro lugar, não falo mal do teatro. Rebelo-me apenas contra esta fórmula idiota: cinema-teatro popularizado. O cinema existe por si só. O cinema é independente. Não precisa do teatro.

- Mas quase todos os cineastas aproveitam os temas teatrais mais conhecidos para as suas realizações.

- ... o que é um grande erro. Uma grande incompreensão da verdadeira finalidade da sétima arte.

- O cinema não é uma arte. É uma indústria.

- Leia Moussinea: "Le cinéma est un art et l'industrie cinématrographique n'est á cet art que ce que l'industrie du livre, par exemple, est á la littérature." Maior lógica é impossível.[...] (Revista Pra você, Recife. 22 de fevereiro de 1930. Edição No 01)

A primeira edição da Revista Pra Você em fevereiro de 1930 contou com um texto intitulado "Diálogo de rua" no qual o cinema é alvo de uma discussão acirrada. A sétima arte foi colocada num lugar de conflito entre aqueles que a apoiavam e os que criticavam o seu caráter artístico exaltando-o como devastador da verdadeira arte. Mas em sua defesa partem os "modernos", em oposição àqueles que não gostam do cinema, os "velhos": "E só por 'esnobismo' os moços procuram ser velhos" (Revista Pra você, Recife. 22 de fevereiro de 1930. Edição No 01).

$\mathrm{O}$ ataque ao cinema é dado pelo questionamento de seu caráter enquanto arte, discurso presente na primeira metade do século XX. Utilizando como argumento o fato da indústria cinematográfica ser responsável pela transformação do cinema num comércio, num mercado. Em oposição a esse pensamento, a teoria contemporânea do cinema propõe pensar que a circulação comercial dos filmes define a modernidade cinematográfica, pois é através dela que encontramos os novos meios de fazer cinema e sua capacidade de expansão. Segundo Tom Gunning: "Poder-se-ia argumentar que técnicas de circulação definem as transformações convergentes na tecnologia e na indústria que chamamos de modernidade" (GUNNING, 2004: 33). Por modernidade, Gunning refere-se à mudança nas experiências, nas tecnologias do gênero, que são importantes para se pensar as transformações sofridas pelo cinema enquanto prática social.

A história do cinema em Pernambuco tem como um dos seus principais momentos a fase do denominado Ciclo do Recife (1923-1931), quando surgiram as primeiras filmagens silenciosas realizadas no estado. Produções que evidenciaram, conforme aponta o pesquisador Paulo Carneiro da Cunha Filho (2010), a utopia provinciana recifense. Um desejo de 
modernidade, da eclosão do espírito moderno na periferia do capitalismo, que buscou apropriar-se do fazer cinematográfico e seus instrumentos de produção

Neste período foram feitos dezenas de filmes silenciosos, alguns deles circulando pelo Brasil. Sendo a produtora Aurora Filmes, fundada por Edson Chagas e Gentil Roiz, a mais conhecida. O alcance desse movimento realizado de forma quase que artesanal e a sobrevivência dos filmes mais importantes fez com que muitos pesquisadores estivessem atentos às particularidades do movimento. O Ciclo findou-se no mesmo momento em que chega ao Brasil a tecnologia da sonorização, através das produções americanas, marcando novas experiências para as salas de cinema locais. O Ciclo do Recife encerrava suas atividades de oito anos de produção e a cinematografia local ingressava em um período de escassez.

Com a chegada do cinema sonoro, Pernambuco sofreu ainda mais com a desleal concorrência das películas americanas produzidas pela mais forte indústria dos filmes: Hollywood $^{1}$. Vale ressaltar que a hegemonia hollywoodiana surgiu quando a indústria cinematográfica europeia, até então a mais poderosa e conhecida do mundo foi afetada pela Primeira Guerra Mundial.

Quando o cinema deixou de ser visto como um mero registro natural e foi incrementado pela narrativa ficcional percebeu-se então o potencial do filme como produto. “Teve início, então, a fabricação em massa de 'fitas de cinema' e, junto com ela, a constituição de uma grande estrutura mundial para sua propagação e venda" (BUTCHER, 2004: 16).

Essa forma de produção em larga escala começou na Europa. Contudo, devido a inúmeras dificuldades, dentre elas financeira por conta da guerra, a indústria europeia diminuiu seu fluxo. Com o enfraquecimento dessa produção, os EUA começaram a exportar vários filmes, superando a produção do continente europeu e estabelecendo uma hegemonia mundial. Como observou Jorge Nóvoa, os americanos notaram que o cinema pode ser vendido em toda parte do mundo (NÓVOA, 2012: 20).

Desde finais da Primeira Guerra Mundial, o cinema norte-americano ocupou seu lugar privilegiado nas salas de cinema do Brasil. Em 1925, o Rio de Janeiro havia exibido 1.065 filmes estadunidenses, enquanto o cinema francês ocupava o segundo lugar com 85 exibições (SIMIS, 2008: 75). A disparidade nas estatísticas nos revela o intenso fluxo de filmes hollywoodianos no Brasil, uma supremacia existente até hoje.

No final da década de 1920, Hollywood vai protagonizar uma das maiores transformações da história do cinema. O cinema até então mudo, vai começar a apresentar 
seus primeiros experimentos com som. Em 1927, a Warner Bros lança nos EUA o filme The Singer Jazz, no qual alguns números musicais do ator Al Jolson e duas outras cenas são apresentados com a tecnologia de som. No ano seguinte, é lançado também pela Warner o primeiro filme com som totalmente falado, o The Lights of New York. Pioneira dos filmes falados, a Warner revolucionou a indústria cinematográfica que passou a substituir os filmes mudos pelos famosos talkies, como ficou conhecido. Em pouco tempo, desde seu surgimento, a tecnologia da sonorização já era uma realidade nas salas de exibição brasileiras.

As transformações nos modos de fazer cinema também trouxeram grandes mudanças nas salas de exibição e nos modos de diversão pública no Brasil. O encantamento pela sétima arte fez com que esses espaços de lazer crescessem cada vez mais nas cidades brasileiras. Segundo a historiadora Sylvia Couceiro, "no Brasil, até a poucos anos atrás, as diversões públicas, a festa e o lazer eram territórios quase exclusivos de antropólogos, folcloristas e alguns sociólogos" (COUCEIRO, 2003: 5). Os historiadores se mantiveram afastados desse terreno desconhecido. A partir dos anos 1990, a difusão da História Cultural no Brasil fez proliferar estudos sobre as práticas culturais e de lazer nas cidades. Levando em consideração, especialmente, os significados desse lazer para as práticas sociais, ponderando os modos de diversão como parte das relações sociais, simbólicas e formadoras. O lazer é visto então como um lugar de conflitos, de relações, de trocas, de sentimentos, de paixões, de formação da identidade da própria cidade.

O Recife, que além de centro administrativo era um importante palco da vida cultural pernambucana, possuía na primeira metade do século XX inúmeros espaços de lazer: bares, restaurantes, ambientes esportivos, clubes e diversas salas de cinema distribuídas em vários bairros da cidade. Os cinemas disputavam o público com a exibição dos principais filmes internacionais, especialmente os norte-americanos que dominavam as sessões.

As principais e primeiras salas de cinema da cidade foram o Pathé e Royal, ambas fundadas em 1909. Em 1910, foi a vez do cinema Helvética, propriedade da Girot \& Cia, na Rua da Imperatriz, bairro da Boa Vista. Um ano depois, foi inaugurado na Rua Barão de São Borja, também no bairro da Boa Vista, o Polythema, que em 1932 viria a pertencer ao grupo do empresário Luiz Severiano Ribeiro. No ano de 1913, inaugurava-se o Teatro Moderno, que em 1915 passou a funcionar também como cinema, localizado na Praça Joaquim Nabuco no bairro de Santo Antônio. Em 1915, também foi inaugurado o Cine-teatro do Parque, na Boa Vista. Com o aumento no número de cinemas, os aspectos técnicos passaram a ser determinantes para atrair a clientela e vencer a concorrência, especialmente a partir de 1930. 
Durante a década de 1920, o Cine-Teatro Moderno se tornou uma das principais salas da cidade fazendo concorrência com o Cine-Teatro do Parque. Fundado em 1915, o famoso Teatro do Parque, localizado na Rua do Hospício, passou a funcionar como cinema um mês depois de sua inauguração. Pertencente ao Comendador Bento Luís de Aguiar, em 1929 o cineteatro foi arrendado ao empresário Luiz Severiano Ribeiro, que empreitou diversas mudanças naquele espaço. Tornando o Parque a sala de cinema mais luxuosa da cidade.

De acordo com a análise de Lêda Dias, o alto investimento atraído por Severiano Ribeiro ao Cine-Teatro do Parque foi um risco do qual o empresário saiu vitorioso:

\begin{abstract}
O mercado cinematográfico do Recife, no final dos anos 20, segundo crônica da época, enfrentava a apatia do grande público, que passado o impacto que o surgimento do cinema causara, esvaziava as sessões mesmo quando apresentados bons filmes através de uma propaganda ruidosa. Os empresários do ramo, desencorajados pela ausência do público, não se arriscavam a investir na construção de cinemas mais confortáveis ou na adaptação das casas já existentes. O público, por sua vez, cada vez mais se distanciava do cinema. Esse círculo vicioso foi quebrado pela iniciativa de Luiz Severiano Ribeiro em arrendar e reformar o Parque, transformando-o numa casa que respondesse às exigências de conforto que a população pedia. (DIAS, 2008: 62).
\end{abstract}

Através dessa revitalização, o Parque se tornou um dos mais soberbos cinemas da capital pernambucana. Logo em seguida, ao final da década, várias salas de exibição tiveram de se renovar e buscar formas de atrair o público. Além de uma sala digna de elogios, o projeto astucioso de Severiano Ribeiro trouxe para o Recife grandes filmes que modificariam os hábitos cinematográficos da cidade. Um prelúdio para as transformações cinematográficas que estavam para acontecer com a alvorecer da década de 1930.

Após a sua reforma, o Parque voltou a funcionar em 29 de julho de 1929, trazendo na sua programação o filme Ben-hur (1925), distribuído pela Metro-Goldwyn-Mayer. A reestreia do Parque contou com um convite especial ao Governador de Pernambuco, feito pelo próprio representante da Metro, o Sr. J. Quevedo Lopes (A Província, Recife, 26 de julho de 1929, p. 4). Compareceram no dia da reabertura o então governador Estácio Coimbra, o senador Júlio Bello, o prefeito do Recife Francisco da Costa Maia, representantes da chefia da polícia e dentre outras autoridades locais.

O cinema fora proclamado pela imprensa local como o mais confortável e elegante da capital. Na noite de sua reabertura continha as 950 poltronas completamente cheias, até mais do que deveria. Os jornais teceram duras críticas à organização da casa por vender mais do que a lotação do cinema cabia. Como resultado, várias pessoas assistiram as 14 partes do filme em pé, sem que nada fosse feito pela gerência do Parque para resolver o desagradável 
problema. No mais, tudo correra bem na exibição da película: "farta iluminação, salões confortáveis, orquestra magnífica e a fita, 'Ben-Hur' (1925), a melhor produção cinematográfica que apareceu no Recife" (A Província, Recife, 30 de julho de 1929, p. 2). Com o título original de "Ben-Hur: A Tale of the Christ", este filme foi dirigido pelo cineasta americano Fred Niblo e é a segunda adaptação para o cinema do romance de Lew Wallace. É considerado um dos filmes mudos mais caros já realizados, cujo orçamento é estimado de quase quatro milhões de dólares. Um filme bastante aclamado pela crítica local que permaneceu um bom tempo em cartaz, lotando a sala em suas apresentações, fato do qual o jornal A Província escreveria na coluna "Theatros \& Cinemas":

\begin{abstract}
Há mais de uma semana que "Ben-hur", a magnífica película da "Metro", está no cartaz do "Cinema-Parque". É um fato, esse, digno de nota, pois, há quinze dias atrás ninguém acreditaria, no Recife, que se pudesse verificar um fato de tal natureza. Acostumados, como estamos, aos três ou quatro programazinhos por semana, nos melhores cinemas, é realmente para causar espanto, um salão cinematográfico que se encha, toda noite, durante dez dias, para assistir a mesma fita.

O fato indica [...] que o Parque se afirmou, desta vez, vitoriosamente no nosso meio cinematográfico.

Desapareceu a "caveira de burro" que se alojara, por longos anos, no cinema da Rua do Hospício. Segundo os anúncios dos jornais - embora a gente não se deva fiar nos reclames de sensação - o "Parque" terá artilharia grossa para bombardear os seus concorrentes às preferências da plateia: mais de 60 fitas, todas ao jeito de "Ben-Hur" e "Metropolis", exemplo das grandes superproduções modernas [...]. (A Província, Recife, 7 de agosto de 1929, p. 2).
\end{abstract}

Pouco tempo depois, sob o projeto de transformação da sala promovido por Severiano Ribeiro, o Teatro do Parque também foi o cenário da mais significativa estreia do cinema na cidade: a sonorização cinematográfica. Com ela, o cinema passaria a completar o seu espetáculo agregando todo poder tecnológico possível da sétima arte. As experiências do público foram transformadas pelas novas sensibilidades trazidas pela inovação da sonorização.

O primeiro filme sonoro exibido em Pernambuco foi The Divine Lady (1929). Estrelado por Corinne Griffith, teve seu lançamento na sala da Rua do Hospício em 24 de março de 1930. Logo em seguida, entrara em cartaz o primeiro filme sonoro falado ${ }^{2}$, The Broadway Melody (1929). Os filmes obtiveram rápido sucesso, o Cinema do Parque não estava trazendo "simples" produções internacionais, mas sim o melhor do cinema hollywoodiano. 


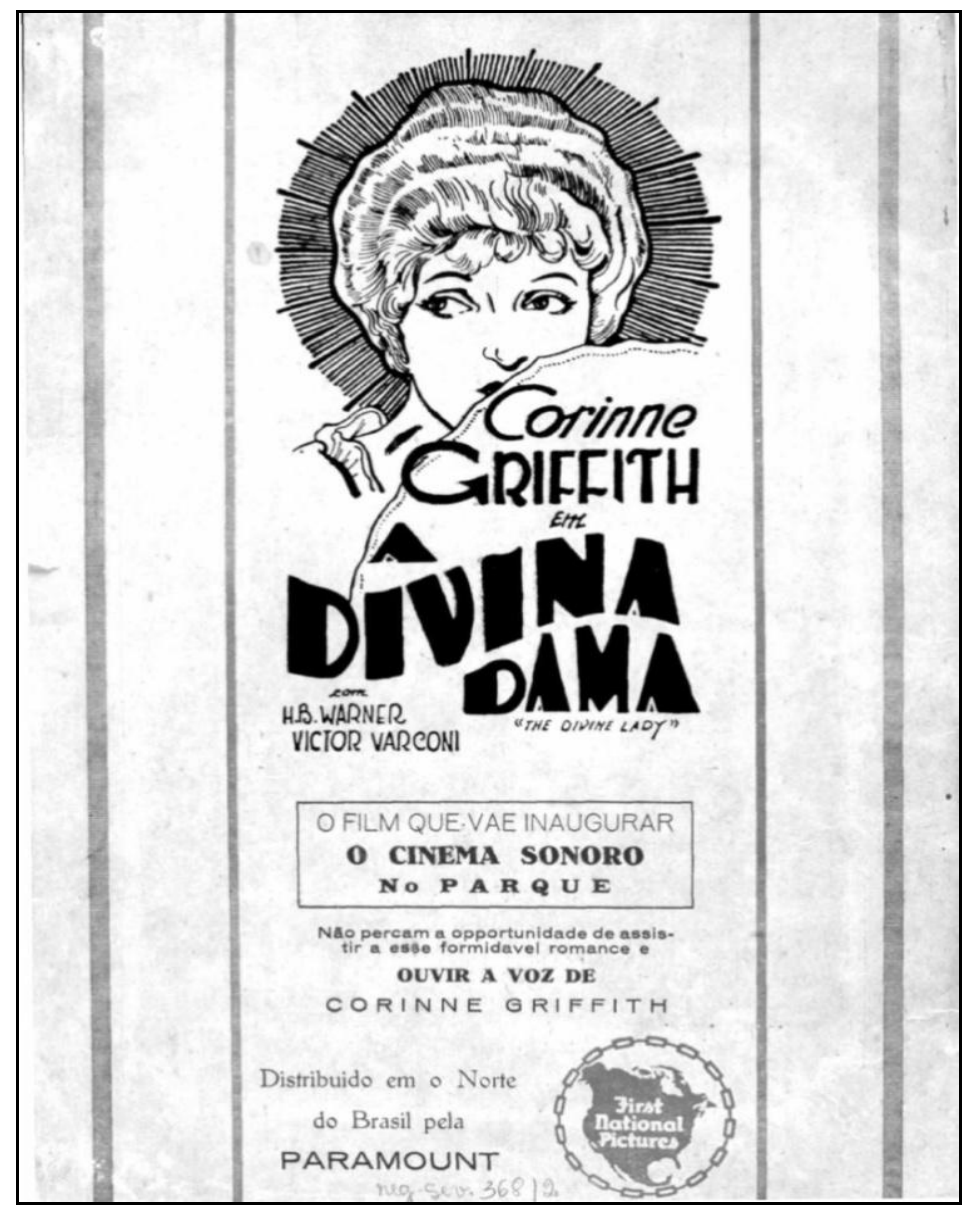

Figura 1 - Cartaz divulgado na primeira edição da Revista Pra Você, em 22 de fev. de 1930.

Ambos os filmes concorreram ao Oscar 1930, ocorrido em abril do mesmo ano, segunda edição do evento de premiação cinematográfica da Academia de Artes e Ciências Cinematográficas. The Broadway Melody foi o grande vencedor na categoria melhor filme, enquanto que The Divine Lady rendeu a Frank Lloyd seu primeiro Oscar de melhor direção. As atrizes Corinne Griffith (The Divine Lady) e Bessie Love (The Broadway Melody) também pleitearam o prêmio de melhor atriz, mas a estatueta ficou com Mary Pickford, do filme Coquette (1929).

Um mês antes de seu lançamento, a novidade do cinema sonoro já era exaltada pelos principais veículos de comunicação da cidade. Em sua primeira edição, a revista Pra Você faz referência A Divina Dama (título em português de The Divine Lady), exaltando a grande oportunidade que o público recifense teria. A revista de proprietária da Empresa Diário da Manhã S.A. publicava semanalmente matérias sobre vida social, cultural, explorando a moda, a arte e a literatura no Recife, tendo dentre os seus colaboradores, nomes de prestígio na cena pernambucana como Jorge de Lima, Álvaro Lins, Aurélio Buarque de Holanda, Josué de Castro e Mário Melo. As propagandas avulsas da revista noticiavam a inauguração e 
destacava: "não percam a oportunidade de assistir a esse formidável romance e ouvir a voz de Corinne Griffith" (Revista Pra você, Recife, 22 de fevereiro de 1930. Edição No 01). A ênfase dada em letras ampliadas ao "ouvir a voz de" revela o quanto à novidade do cinema sonoro era significativa para o público recifense.

Na mesma edição, a matéria principal da coluna cinematográfica da revista dizia sobre o filme da Paramount:

Corinne Griffith, a beleza mais pura e mais suave da tela prateada, a "Nossa Senhora do Cinema", como chamou Guilherme de Almeida, terá o primeiro papel feminino em “A Divina Dama”, a grande produção sonora da First National que inaugurará a nova fase do Theatro do Parque.

Os "fãs" de Pernambuco terão a ventura de assistir, na tela, os amores célebres de Lord Nelson e Lady Hamilton. Por sua vez, o vitaphone transmitirá á nossa plateia a voz cariciosa de Corinne cantando as melodias mais bonitas deste mundo. Pelo fato de ser o cinema sonoro uma novidade entre nós, e por ser, ainda, "A Divina Dama" um grande filme, é de prever um êxito formidável na reabertura do cine-teatro da Rua do Hospicio. (Revista Pra você, Recife, 22 de fevereiro de 1930. Edição No 01).

Para acompanhar a empolgação da novidade e não perder seus clientes, não tardou que outras salas da cidade passassem a oferecer a sonorização. Em julho do mesmo ano, “o Moderno firma contrato com a Companhia Brasil Cinematográfica, para exibir os filmes sonoros do Programa Serrador e em setembro o cinema é arrendado pela empresa Avelino \& Cia” (ARAÚJO, 2011: 10). No mesmo mês, o Royal também passou a exibir filmes sonoros, anunciando a tecnologia como sendo de fabricação brasileira.

Num contexto em que a cidade buscava a "modernização", traçados pela construção de novos hábitos culturais e novas tecnologias, a transformação das salas de cinema do Recife tornava-se um fator característico para o projeto modernizante. A cidade periférica do capitalismo, conforme os termos de Cunha Filho (2010), entrava na era do cinema sonoro e reconhecia através desses espaços de lazer a aproximação com as principais salas do país e do mundo, o "novo" Recife, em consonância as novidades tecnológicas.

Inversamente proporcional ao desenvolvimento tecnológico das salas de cinema do Recife e ao fascínio pelas grandes produções estrangeiras estava a atuação dos cinegrafistas locais. O cenário crescente que viviam as salas do Recife ao final da década de 1920, infelizmente não foi o mesmo ambiente encontrado pelos cineastas locais, que enfrentavam diversas dificuldades financeiras. Muitas empresas cinematográficas recifenses foram à falência, como a Aurora Filmes que encerrou suas atividades em 1927. Alguns cinegrafistas sobreviveram produzindo pequenos comerciais e outros deixaram o Recife para buscar oportunidades em outras cidades, como é o caso de Edson Chagas, um dos principais personagens do Ciclo do Recife, que foi para São Paulo e posteriormente Rio de Janeiro. 
Agravando cada vez mais a situação, o ano de 1930 foi um divisor de águas na história da cinematografia pernambucana, com a chegada do cinema sonoro.

As condições precárias em que o cinema mudo pernambucano era produzido se tornaram um desafio ainda para seus organizadores, cujo público preferia as novas tecnologias. O filme No Cenário da Vida (1931) produzido pela Liberdade Filme foi a última produção do movimento do cinema mudo no Recife. Em 1932, a empresa de Eusebio Simões \& Djalma Simões leiloava o estoque da Aurora Filmes. Dentre o material estavam os filmes $A$ Filha do Advogado, Aitaré na Praia, Jurando Vingar e Retribuição (A Província, Recife, 15 de maio de 1932, p. 4). Apesar da falência da Aurora, o cinema no Recife continuou a existir, em suas novas formas. Segundo Antonio Paulo Rezende: "Outras figuras se destacaram, como Jota Soares, Pedrosa da Fonseca, Pedro Salgado e tantos outros. O Recife convivia também com salas cinematográficas que exibiam com destaque as produções estrangeiras" (REZENDE, 2005: 99).

Se por um lado ao entorno do Ciclo do Recife e de sua produção ficcional criou-se, especialmente pela imprensa e as pesquisas desenvolvidas sobre o tema, uma áurea mistificadora, a decadência do Ciclo do Recife fez com que surgisse sobre o período posterior ao movimento um tom melancólico, sendo atribuído ao cinema sonoro e falado a grande culpa pela deterioração técnica e produtiva do cinema pernambucano. No entanto, a história do cinema pernambucano não se limita a produção de ficcionais. Novos movimentos, novas produções e outras formas de fazer e discutir o cinema surgiriam na capital pernambucana após a chegada do cinema sonoro.

Retomar o espaço perdido no início dos anos 30 foi algo muito difícil para os cineastas locais. Não havia o investimento necessário para tal, enquanto que a indústria norte-americana se fortalecia cada vez mais. Para reconquistar o mínimo de espaço, os produtores não só do Recife como de todo o Brasil, tiveram de contar com o apoio e incentivo de políticas públicas voltadas ao cinema nacional. Os novos ares da política nacional a partir de 1930 foram significativos para esse processo.

A década de 1930 foi marcada por inúmeras mudanças no campo político, social e cultural. A mais relevante delas, obviamente, foi a tomada de poder feita pelo movimento de 1930 que colocou o então governador do Rio Grande do Sul, Getúlio Vargas, como chefe da nação, primeiramente em caráter provisório. Nas eleições ocorridas em $1^{\circ}$ de março de 1930 , o candidato governista e então presidente do estado de São Paulo, Júlio Prestes saiu vitorioso. O futuro presidente deveria assumir o cargo em 15 de novembro do mesmo ano. Porém, a posse de Prestes foi interceptada pelo acontecimento desencadeado a 3 de outubro de 1930, 
que se espalhou por todo o Brasil tendo o apoio de vários estados brasileiros, incluindo Pernambuco. Em de outubro de 1930, o Jornal do Recife exaltava em sua manchete "Cada vez mais triumphante a Revolução Brasileira!”, destacando a vitória do golpe em Pernambuco e o crescimento vitorioso do movimento em todo o Brasil. (Jornal do Recife, Recife, 8 de outubro de 1930, p. 1).

$\mathrm{Na}$ vitória dos revolucionários, o candidato da Aliança Liberal, Getúlio Vargas, derrotado na eleição de março, assumiu a chefia do Governo Provisório. Com o fechamento do Congresso Nacional e as assembleias estaduais e municipais, Vargas passou a governar através de decretos-lei. O primeiro momento pós-revolução conviveu no conflito entre as esferas remanescentes dos vitoriosos, fortemente representada pelo tenentismo e os oligarcas dissidentes que apoiaram a revolução. Os tenentes eram favoráveis a um regime forte, centralizador, reformista e apartidário; enquanto que os oligarcas dissidentes defendiam propostas liberais e federativas (PANDOLFI, 2012: 17-18).

Como nos mostra a historiadora Dulce Pandolfi (2012), as primeiras medidas adotadas pelo Governo Provisório foram intervencionistas e centralizadoras, inspiradas nas reivindicações tenentistas. O Governo fez também significativos investimentos na área social, sendo criados o Ministério do Trabalho, Indústria e Comércio (chamado de Ministério da Revolução por Lindolfo Collor) e o Ministério da Educação e Saúde Pública.

A década que iniciara com um novo regime político, foi também abalizada pela disseminação do cinema sonoro nas principais cidades do Brasil. Antes do Recife, ainda em 1929, os filmes sonoros chegaram à outras capitais brasileiras. A adaptação das salas de cinema das cidades de São Paulo e Rio de Janeiro para a projeção de filmes sonoros foi rápida, tendo São Paulo inaugurado a nova tecnologia no Brasil, no Cine Paramount, a 13 de abril de 1929. Evento referenciado pelo jornal recifense A Província como o primeiro filme falado da América do Sul. No dia foi exibido o filme Alta Traição (1928). O evento contou com a assistência da polícia civil para o estabelecimento de cordões de isolamento, evitando atropelamentos devido ao grande fluxo de espectadores (A Província, Recife, 14 de abril de 1929, p. 1). A participação da polícia para a manutenção da ordem nos mostra a dimensão que foi a chegada do cinema sonoro na capital paulista. Dois meses depois, o cinema falado chegou ao Palácio Theatro, Rio de Janeiro, evento que contou com a presença do então presidente Washington Luís. A exibição na capital federal foi promovida pelo dono do teatro, Francisco Serrador, empresário espanhol do ramo do entretenimento, incontestável nome da cinematografia no Brasil (FREIRE, 2013: 31). 
Acerca das tecnologias dessas salas, o pesquisador Rafael de Luna Freire afirma que “esses luxuosos palácios cinematográficos podiam arcar com a compra e instalação dos caros e importados projetores Western Electric conjugados para os sistemas Vitaphone (som em discos) e Movietone (som ótico)" (FREIRE, 2013: 31). Mesmo tipo de aparelho que seria utilizado pelo Cinema do Parque no Recife no ano de $1930^{3}$. Sobre essas tecnologias, os jornais recifenses informavam ao público:

\begin{abstract}
$\mathrm{Na}$ América do Norte, onde ainda não dominou completamente o novo processo cinematográfico, são usados dois processos para o cinema falado: o "movietone" e o "vitaphone". O primeiro processo consiste em ter o som, a música, os ruídos e a voz gravados no próprio filme; o outro, tudo isso gravado em discos. Os alemães utilizam um processo diferente, com a impressão sonora em cintas de aço. As quatro grandes marcas que apresentarão produções suas no movietone inaugurado agora no Rio, serão a Metro, Tiffany, Fox e First National. (A Província, Recife, 26 de junho de 1929, p. 2).
\end{abstract}

Pouco tempo depois, cidades como Niterói, Santos, Piracicaba, Vitória, Curitiba e Porto Alegre também receberam o cinema sonoro ainda nos idos de 1929, utilizando equipamentos sonoros da Radio Corporation of America (RCA), como o Photophone RCA. O ano de 1930 marcou a disseminação do cinema sonoro no, então, "norte" do país, chegando em especial nas principais capitais: Recife, Fortaleza e Salvador. Assim como em Pernambuco, a difusão do cinema sonoro no Ceará contou com a administração do empresário Luiz Severiano Ribeiro ${ }^{4}$.

Três anos depois, o compositor carioca Noel Rosa lançava a música Não tem tradução. Os versos iniciais, ao ritmo do samba, apontavam para a situação da sétima arte no Brasil: "O cinema falado é o grande culpado da transformação". Noel citava através da música a influência americana exercida sobre a cultura brasileira, bastante presente na transição do cinema mudo para o falado.

Além de modificar os costumes, falas e hábitos, a disseminação do cinema falado/sonoro também foi responsável pela crise em alguns setores culturais, sendo apontado por muitos jornais como o grande rival do cinema mudo, do teatro e dos próprios músicos, que na época do cinema mudo tinham a possibilidade de executar as trilhas dos filmes durante as sessões. O Jornal do Recife, em 8 de fevereiro de 1930 mostrava as difíceis condições em que os músicos se encontravam no mundo todo, especialmente depois da introdução da sonorização no cinema, algo que agravava a falta de serviço (Jornal do Recife, Recife, 8 de fevereiro de 1930, p. 3).

O rebuliço causado pelas novas sensibilidades proporcionou inúmeras discussões entre diversos jornais e revistas da época. Na estreia do cinema falado em São Paulo, o jornal $A$ 
Província associava a tecnologia ao progresso de uma cidade, referenciando que "hoje uma grande cidade sem o cinema falado está fazendo guerra ao progresso" (A Província, Recife, 16 de abril de 1929, p. 2). Através da chegada do som, o cinema acentuava seu caráter conflitante, exaltando nas novidades o combate ao atraso em prol de uma determinada modernidade.

As circulações das novas tecnologias instituem a modernidade cinematográfica, modificando as experiências do ver e sentir o cinema e a própria representação do mundo. $\mathrm{O}$ som trouxe para os espectadores uma maior aproximação com os seus ídolos. Como era fascinante, exaltavam os jornais, por exemplo, ouvir a voz da Corinne Griffith. Por isso é necessário ponderar a questão tecnológica para se compreender não só as transformações no campo do cinema, mas também suas recepções e as estruturas sociais. Sobre essas transformações, ainda antes da chegada do cinema sonoro ao Recife, o jornal A Província enunciava:

E não será, então, somente o orgulho do progresso que nos irá fazer contentes. Poderemos então ouvir a voz dos artistas que mais queremos. Qual será o timbre da voz daquela maravilhosa Billie Dove? E Dolores del Rio? E da magrinha e deliciosa Mary Phibin? O diabo é que pouca gente no Recife sabe falar inglês. Mas valerá a pena, para ouvir as "estrelas" maravilhosas, procurar os professores de línguas. Estes é que lucrarão: compreenderão as fitas e ganharão o dinheiro da futura legião de estudantes. (A Província, Recife, 16 de abril de 1929, p. 2).

Um dos debates acentuados pelas novas experiências relativas à sétima arte versava sobre receptividade da língua estrangeira, pois, ainda não havia dublagem ou legendas. Em 1929, o jornal recifense destacava a eficiência deste novo cinema apenas perante plateia culta: “O que não resta dúvida é que o cinema falado só se presta, entre nós, para as plateias cultas. Para gente que saiba inglês ou alemão. É de crer, assim, que o movietone apenas funcione em dias especiais (...)" (A Província, Recife, 26 de junho de 1929, p. 2).

Segundo os jornalistas da época, a voz no cinema tornou-se a uma inimiga do grande público. O cinema passava a ter um caráter elitista, pois, para se compreender esta nova tecnologia era preciso dominar outras línguas. Por isso, dava-se uma atenção especial aos filmes que possuíam poucas falas, facilitando assim a compreensão do espectador. Todavia, pensar o cinema a partir destes aspectos é considerar também as resistências e apropriações que seu uso denotou. Obviamente, o caráter moderno do cinema sonoro fez com que as pessoas dos mais variados grupos sociais se interessassem pelos filmes, como resultado: costumes, expressões e práticas foram ressignificadas a partir desse contato. Um reflexo disso é a utilização constante de termos e expressões em inglês na música popular a partir de 1930. A presença do cinema falado vai incorporar na cultura brasileira falas e gírias americanizadas. 
Em 1944, o compositor pernambucano Nelson Ferreira lança o frevo Bye, Bye, My Baby, cujos versos exaltavam essa influência em trechos como "Amor eu vou-me embora (...) Só te vejo amanhã, my baby, bye, bye" e "Atualmente só se fala o inglês, está tudo diferente, diferente pra chuchu / é yes, kiss me, ok, até eu só sei dizer I love You (...)”.

No entanto, como retrata a canção "Não tem tradução" de Noel Rosa, há também a resistência "dessa gente que sente que o barracão vale mais que o xadrez" aos novos costumes. Em um desses versos, Noel exalta que "Essa gente que hoje em dia tem a mania da exibição / Não entende que o samba não tem tradução no idioma francês", menção direta ao país dos Irmãos Lumière. Criticamente, a letra da música de Noel acentuava que "Amor lá no morro é amor pra chuchu /As rimas do samba não são I love you" / [...] E esse negócio de alô, alô boy e alô Johnny / só pode ser conversa de telefone".

A questão linguística também era fortalecida pela presença dos próprios estrangeiros nas cidades brasileiras. Especialmente as portuárias e/ou aquelas que contavam com empresas estrangeiras, como por exemplo, as companhias inglesas Pernambuco Tramways e da Great Western instaladas no Recife, o que fortaleceu ainda mais a popularização da língua inglesa ${ }^{5}$.

Contudo, as críticas mais fortes ao cinema falado não foram dadas pela questão da compreensão linguística, mas sim pelo próprio caráter da linguagem cinematográfica: a fala, para os críticos, era um inimigo que deveria ser combatido porque tirava do cinema a sua essência como arte. Grupos se formaram contra os filmes sonoros em favor do cinema mudo. Em 1928, no Rio de Janeiro, surgiu o primeiro periódico brasileiro de difusão e discussão sobre estética cinematográfica, $O \mathrm{Fan}$, influenciada por discussões trazidas da Europa que exponha o potencial artístico do cinema. A revista, organizada pelo Chaplin Club, realizou um amplo debate sobre a linguagem cinematográfica na capital federal, tendo como membros Plínio Sussekind, Otávio de Faria, Almir Castro e Cláudio Mello.

O Chaplin Club defendia o cinema silencioso em oposição ao sonoro, não por acaso levava em sua denominação um dos principais nomes do cinema mudo ${ }^{6}$. A revista $O$ Fan, órgão oficial do Chaplin Club, tinha circulação restritiva e sua última edição foi lançada dois anos depois, em dezembro de 1930. Por não estar em consonância com o cinema sonoro, o fortalecimento da tecnologia cinematográfica na transição dos anos 20 aos 30 no Brasil foi determinante para a dissolução do grupo, mas suas ideias ainda foram remanescentes em algumas personalidades que tentavam teorizar o cinema partindo em defesa do cinema silencioso. Em 1931, o próprio Charles Chaplin se rende, de certa forma, a nova tecnologia quando realiza o filme City Lights (1931), lançado a época em que o filme sonoro já era uma 
hegemonia nos EUA. O cineasta buscou então harmonizar a mímica silenciosa com inserção de uma trilha sonora.

Em Pernambuco, na defesa do cinema mudo destaca-se a figura de Evaldo Coutinho, um dos responsáveis pela manutenção da experiência do cinema após o Ciclo do Recife. Escreveu sobre cinema nos jornais recifenses, atuando como como crítico de filmes no Jornal do Commercio e posteriormente no Diário Carioca. Coutinho foi bastante influenciado pelas discussões promovidas pelo Chaplin Club, através da circulação da revista $O F a n$. Segundo Paulo Cunha Filho, a revista:

[...] trazia para o Brasil o debate europeu do início dos anos 1920, no qual o filme é analisado como potencial artístico. Mas apenas na medida em que o cinema "silencioso" perseguia modelos que se afastava do teatro e da literatura. O objetivo assumido do jornal (posteriormente revista) O Fan é "o estudo do cinema como arte”. Octávio de Faria, um dos principais intelectuais ligados ao Chaplin Club, vai publicar artigos em que discute as relações entre imagem e palavra, na perspectiva de uma linguagem específica do cinema. Na realidade, esses ensaios defendem uma "oposição" entre a imagem e a palavra, esferas inconciliáveis - para o bem do cinema que fugisse das armadilhas da teatralidade e da litera(tura)lidade. (CUNHA FILHO, 2014: 39-40)

Para eles, imagem e palavra pertenciam a dois grupos distintos que não deveriam se misturar. Cabia ao cinema o trabalho com a imagem, enquanto que a literatura e o teatro com a fala. O som e a cor desvinculariam o cinema da sua essência como arte autônoma ${ }^{7}$. A chegada do cinema sonoro era vista como uma teatralização do cinema, algo que prejudicaria a sua essência como arte. O filme sonoro é tratado pelo $O$ Fan como uma "ideia monstruosa" que responde à "imbecilidade do público", ainda de acordo com Paulo Cunha Filho, "no projeto estético do Chaplin Club, ou melhor, nos sonhos dos seus cinéfilos, em algum momento os empresários americanos iriam rever suas posições e fazer o cinema retornar ao leito perfeito do filme mudo" (CUNHA FILHO, 2014: 43).

Este pensamento também é compartilhado por Evaldo Coutinho, em defesa do cinema mudo. Ideia que vai permanecer no autor durante anos, como podemos notar quando na década de 1972 publica o livro A Imagem Autônoma. Para ele, a fala só havia afastado o cinema de sua essência e o vinculava a outras expressões artísticas. Numa entrevista concedida ao Diário de Pernambuco durante os seus 90 anos, em 2001, Evaldo Coutinho fala sobre seu livro enfatizando sua proposta teórica para o cinema:

"Acho que uma filosofia do cinema nós só podemos encontrar diante do cinema mudo, preto e branco. $\mathrm{O}$ cinema falado não nos dá, não nos favorece, não estimula sobre uma filosofia do cinema. Porque o cinema falado já está no teatro" ${ }^{\text {. }}$. 
As principais críticas ao cinema falado estavam justamente na remoção de sua autonomia ao incrementar valores de outras artes, projeto de combate de Coutinho e dos membros do Chaplin Club. Porém se para uns a essência do cinema estava nessa desvinculação, para outros o som era mais um aperfeiçoamento da sétima arte. Encantava o espectador poder sentir novas sensações. As correntes que lutaram contra o cinema falado e sonoro durante a década de 1930 foram amplamente vencidas. Um reflexo disso é a quantidade crescente de salas de cinema que se adaptavam a nova tecnologia e a importação de filmes sonoros que aumentava a cada ano.

Até alguns nomes que combatiam as novas experiências cinematográficas se renderam as mudanças. $\mathrm{O}$ artigo de Luciana Corrêa de Araújo $O$ mercado exibidor do Recife na transição para o cinema sonoro traz um interessante relato do jornalista Luís Maranhão, que depois de assistir ao filme A Divina Dama no Parque escreve o artigo "Cinema sonoro Confesso a derrota”, mudando sua opinião sobre o assunto:

Jornal da Paramount. Um ruído de aeroplano. Achei bom, muito bom mesmo. Depois mais balas, não muito boas. Outros ruídos regulares. Enfim, um jornal apanhado ao ar livre, na confusão de mil e um rumores, não encontrava eu elementos para um juízo seguro.

Veio depois um short da Manon, cantado pelos artistas da Ópera, de Filadélfia. Comecei a me movimentar na poltrona, entusiasmado. Aquilo era bom de fato. A ilusão estava completa. Relembrava os meus tempos de carona incorrigível de companhias líricas, no sul.

[...] Depois, A divina dama. Aí então fui vencido de vez. Não sei se porque sou um fã dedicado de Corinne Griffith, o fato é que gostei francamente do filme, com a sincronização e tudo. Então aquela canção com acompanhamento de harpa foi a pancada que me derrubou de vez. Entretanto, mesmo grogue como estava, constatei que aqueles ruídos de batalha não convencem. Sente-se bem o som feito por máquinas que não se parecem com canhões ("Cinematographia". Jornal do Commercio, Recife, 6 de abril de 1930, p.10).

O cinema sonoro aumentou as possibilidades emocionais ao introduzir de maneira direta um novo sentido: a audição. Era mais um sentido que se integrava àquela arte. Em 1934, as principais salas de exibição da capital pernambucana já possuíam equipamentos para a reprodução dos filmes sonoros. Com a difusão da tecnologia, os realizadores locais também tiveram de se readaptar para resistir às pressões dos filmes estrangeiros.

No Rio de Janeiro, o principal polo de produção nacional se deu através do Cinédia, estúdio idealizado por Adhemar Gonzaga em 1930, que contou também com a presença do diretor mineiro Humberto Mauro, um dos principais nomes do Ciclo de Cataguases, ciclo do cinema mudo mineiro similar ao pernambucano. Com o surgimento da Cinédia, Mauro começa a trabalhar com Adhemar Gonzaga, dirigindo a primeira produção do estúdio, Lábios sem beijos (1930). Uma das principais bandeiras levantada pela empresa junto com a revista 
Cinearte, editada por Adhemar Gonzaga e Mário Behring, era lutar pelo apoio do governo brasileiro ao cinema nacional. A Cinédia também realizou experimentos com o cinema falado. Em 1933, a Cinédia produziu A Voz do Carnaval, filme sonoro no qual a cantora Carmen Miranda faz uma de suas primeiras aparições cinematográfica

Diversos fatores afligiam os cineastas brasileiros: a precariedade técnica comparada aos grandes estúdios estrangeiros, falta de exibidor, inconsistência na programação e o baixo incentivo dos veículos de comunicação e do governo eram reclamações constantes dos realizadores nacionais. Essas questões motivaram cineastas de todo Brasil, formando uma campanha política que buscava apoio do governo para sanar os problemas cinematográficos.

Como consequência da campanha iniciada na capital federal, o recém-fundado Ministério da Educação do governo varguista promoveu uma análise do problema em 1932. Sob a condução do ministro Francisco Campos um grupo civil formado por nomes como Adhemar Gonzaga, Mario Behring, Jonatas Serrano, Lourenço Filho, Teixeira de Freitas, entre outros, criou um anteprojeto que se converteu no Decreto-lei 21.240/32.

O decreto foi à primeira resposta do novo governo para as questões cinematográficas nacionais, atendendo aos pedidos dos cineastas. Consistia nos principais objetivos do governo quanto ao cinema. Continha vinte e cinco artigos, do qual considerava o cinema como um benefício à cultura popular, dado ao interesse da indústria e comércio cinematográfico, e buscava incrementar a feição cultural e pedagógica que o cinema deveria ter.

Um destaque especial é dado aos filmes documentários e ao cinema educativo. Explorar os usos políticos e simultaneamente educacionais possíveis por meio do cinema tornou-se uma meta do governo. As exposições iniciais do decreto consideram o potencial propagandístico do documentário, dentro e fora do país; define também o filme educativo como um material de ensino, reconhecendo a sua importância cultural, especialmente na atuação sobre o grande público, e mesmo sobre os analfabetos. Considerando exemplos de outros países, a censura precisaria tomar um cunho cultural para a unidade da nação. Dessa forma, deve funcionar como um serviço único, centralizado na capital do país. Tal medida reflete bem o caráter centralizador do governo, justificado principalmente dos interesses políticos de nomes ligados ao tenentismo e inspirados por ideologias autoritárias e fascistas, que assumiam essa postura, sobretudo em aspectos ligados a cinematografia e a cultura.

Para os realizadores, o decreto serviu como a primeira medida protecionista, garantindo a obrigatoriedade de exibição de filmes nacionais nas salas brasileiras. Por outro lado, nacionalizava a censura cinematográfica, atribuindo ao Ministério da Educação e Saúde o poder de exprobração. Seria considerado motivo de interdição do filme quando contivesse 
qualquer ofensa ao decoro público, sugerir crimes e maus costumes, prejudicasse a cordialidade na relação com outros povos, insultos coletivos ou a particulares ou ferisse a dignidade nacional e abalassem a ordem social.

Compreendendo o poder da propaganda política, o governo do presidente Getúlio Vargas voltou sua atenção ao cinema. Vargas se mostrou favorável aos anseios do cinema nacional, enquanto que a Primeira República se mantinha fechada às reivindicações dos cineastas brasileiros. A "lei de obrigatoriedade de exibição dos filmes nacionais" implementada em 1932 se tornaria uma vitória para a classe, o que faz, nas palavras do historiador Sidney Ferreira Leite, Vargas ser considerado o "pai do cinema brasileiro" (LEITE, 2005: 39). Tal medida contribuiu como um protecionismo ao cinema nacional que convivia com uma concorrência desleal das produções dos Estados Unidos, fabricadas por uma indústria muito bem estruturada.

O cinema se tornaria a partir de 1932 parte da política cultural do governo varguista. O controle e a manutenção do cinema brasileiro estariam sustentados pelos órgãos públicos. Esta relação vai se estender durante o Governo Constitucional (1934-1937) e o Estado Novo (1937-1945), onde novas leis e medidas seriam criadas para uma sistematização do cinema nacional. Se por um lado, os cineastas ganharam com as medidas protecionistas, o governo também foi vitorioso com o decreto. O cinema é uma ferramenta de grande potencial político. Tendo em vista sua presença no cotidiano da população brasileira, o novo regime vai enxergar na sétima arte um caminho para se manter a coesão e unidade nacional.

No Recife, a política varguista vai possibilitar a sobrevivência do cinema realizado na cidade. Os primeiros registros de filmes sonoros produzidos na capital pernambucana por cineastas locais são atribuídos à produtora cinematográfica Meridional Filmes, do cineasta Newton Paiva, principal companhia da década de 1930 e 40. A empresa inaugurou em Pernambuco à tecnologia da sonorização, estando ao lado do governo de Getúlio Vargas e seus representantes locais. Em 1939, a Meridional produziu seus primeiros filmes no Recife, como: A série cinematográfica do jornal Folha da Manhã (trinta volumes entre 1939 e 1940), o filme Mocambos (1939) e as filmagens do III Congresso Eucarístico Nacional (1939), todos eles, versando sobre aspectos políticos e encomendados pelo interventor pernambucano, Agamenon Magalhães.

Após um período de profunda escassez durante a primeira metade da década de 1930, o Recife vai encontrar nos curtas-metragens uma forma de sobrevivência no circuito de produção, trajetória similar ao que aconteceu em outras capitais como Porto Alegre, Salvador, Belo Horizonte e São Paulo ${ }^{9}$. Surgia então uma ampla produção de shorts, especialmente do 
gênero documental, como os cinejornais: noticiários de assuntos diversos como política, cultura e esportes, que entrariam na programação da Lei de Obrigatoriedade de Exibição dos Filmes Nacionais.

O gênero documental foi responsável, nas diversas produtoras brasileiras, pela própria possibilidade de realização dos ficcionais ${ }^{10}$. Através da propaganda governamental e comercial os produtores conseguiam recursos financeiros para os seus filmes de enredo ${ }^{11}$, prática estabelecida desde os anos 20. Num período de dificuldades ao qual foi o início da década de 1930, justifica-se a grande quantidade de curtas e documentais que desempenhavam assim um papel fundamental na possibilidade de existência de uma cinematografia nacional. Os recursos adquiridos com essas películas também permitiriam o incremento das tecnologias e experiências de sonorização. Em muitas cidades como o Recife, foram esses shorts que marcaram a transição do cinema silencioso ao sonoro.

\section{Notas}

\footnotetext{
${ }^{1}$ De acordo com Alexandre Figueirôa: "A chegada do cinema sonoro e as inovações tecnológicas - como o aparecimento da cor - tornavam inviáveis, na região, a realização cinematográfica com a mesma efervescência do que ocorrera nos anos 20. Só nos anos 40, registram-se algumas iniciativas (...)”. (FIGUEIRÔA, 2000: 30).

${ }^{2} \mathrm{O}$ filme falado é dialogado sem legendas, com narração simultânea, enquanto que o sonoro, possuí ruídos, música (muitas delas cantadas pelos próprios atores) e algumas interjeições, mas evitando os diálogos constantes, sendo dessa forma mais apropriada aos locais onde não se falava o inglês.

${ }^{3}$ De acordo com Luciana Corrêa de Araújo: "Os jornais da época informavam que o Parque seria "fechado na última semana de fevereiro, reabrindo na primeira quinzena de março, dotado de aparelho elétrico RCA, para exibir filmes no modelo Vitaphone e Movietone. [...] No dia 9 de março, a imprensa noticia a chegada, pelo navio Itahité, dos quarenta volumes do aparelhamento de som para o Parque, não mais da marca RCA e sim Western, o mesmo dos melhores cinemas do Rio e São Paulo (Paramount, Palácio, Odeon, entre outros), garante a nota de divulgação [...]". (ARAÚJO, 2011: 8).

${ }^{4}$ Responsável também pela estreia do cinema sonoro no Cine Moderno de Fortaleza em 19 de junho de 1930, exibindo Broadway Melody. (FREIRE, 2013: 37).

${ }^{5}$ Ao remeter sobre os anos 30 e 40, a historiadora Zélia de Oliveira Gominho nos revela que "a presença estrangeira no Recife era flagrante, em particular de militares norte-americanos. A ponto de influírem nos hábitos e costumes locais, popularizando a língua inglesa, e se comemorar o dia da Independência dos EUA nos Centros Educativos Operários. Os efeitos dessa influência se faziam sentir até mesmo nas composições de Nelson Ferreira, que lançaria o frevo Bye, Bye, My Baby para o carnaval de 1944" (GOMINHO, 2007: 181-182). ${ }^{6}$ A própria referência a Chaplin é significativa nesse grupo. Chaplin resistiu durante muito tempo a realizar um filme falado, ele afirmava: "Os talkies... podem dizer que os detesto! Eles vão acabar com a arte mais antiga do mundo, a arte da pantomima. Aniquilam a grande beleza do silêncio" (CHAPLIN apud MARTIN, 2005: 108).

${ }^{7} \mathrm{O}$ central esforço de Evaldo Coutinho é "[...] explicar o cinema como arte a partir de sua desvinculação com as demais expressões artísticas tradicionais. A rigor, vem desse modo de entender a arte a ideia de que o cinema, como regime estético autônomo, não poderia ter cor (que é matéria da pintura) ou som (matéria da música)". (CUNHA FILHO, 2014: 47).

${ }^{8}$ Entrevista concedida ao Diário de Pernambuco. Disponível em: <http://www.old.pernambuco.com/diario/2001/07/23/urbana5_0.html> Acesso em: 29/03/2014.

9 Ainda em 1932 começou a circular no Rio Grande do Sul, o cinejornal silencioso Actualidades Gaúchas, produzido pela companhia Leopoldis Filme, dirigida por Italo Majeroni. O filme continha as últimas novidades porto-alegrenses, os últimos acontecimentos políticos e desportivos. Este cinejornal circulou ainda em 1933. Em Salvador, o documentário A Bahia histórica, artística e religiosa, também de 1932, foi outro importante registro
} 
da produção de documentários no norte do país. Nele eram exaltados os aspectos dos "mais sensacionais fatos da história pátria", conforme a descrição do próprio filme, mostrando os monumentos da cidade de Salvador. Fonte: Base de dados da "Filmografia Brasileira" do site da Cinemateca Brasileira, disponível em: <http://cinemateca.gov.br > Último acesso: 14 de julho de 2014.

${ }^{10}$ Foi por causa dos recursos obtidos com o gênero que, por exemplo, a Meridional Filmes realiza em 1942 o primeiro longa-metragem ficcional sonoro de Pernambuco e do Nordeste, O Coelho Sai, dirigido por Newton Paiva.

${ }^{11}$ Segundo Anita Simis: “[...] os documentários e cinejornais, em que predominava a propaganda política e comercial, mantiveram em funcionamento a atividade cinematográfica, proporcionando paralelamente as condições para realização de projetos de filme de enredo. A maior parte destes filmes é de curta-metragem, mas foram eles que em grande parte possibilitaram a produção de filmes de longa-metragem”. (SIMIS, 2008: 81).

\section{Referências Bibliográficas}

ARAÚJO, Luciana S. L. Corrêa. O mercado exibidor do Recife na transição para o cinema sonoro. In: XX Encontro da Compós, 2011, Porto Alegre. 20 Encontro Anual Compós 2011, 2011. v. 1.

BUTCHER, Pedro. A reinvenção de Hollywood: cinema americano e produção de subjetividade nas sociedades de controle. Revista Contemporânea, n.3. 2004.2. Rio de Janeiro: UERJ, 2004.

COUCEIRO, Sylvia Costa. Artes de viver a cidade: conflitos e convivências nos espaços de diversão e prazer do Recife dos anos 20. Tese de Doutorado em História - Universidade Federal de Pernambuco. Recife, 2003.

CUNHA FILHO, Paulo Carneiro da. A Imagem e seus Labirintos: o cinema clandestino do Recife (1930-1964). Recife: Nektar, 2014.

CUNHA FILHO, Paulo Carneiro da. A utopia provinciana: Recife, cinema, melancolia. Recife: Ed. Universitária da UFPE, 2010.

DIAS, Lêda. Cine-teatro do Parque: um espetáculo à parte. Recife: Fundação de Cultura Cidade do Recife, 2008.

FIGUEIRÔA, Alexandre. Cinema pernambucano: uma história em ciclos. Recife: Editora FCCR, 2000.

FREIRE, Rafael de Luna. A conversão para o cinema sonoro no Brasil e o mercado exibidor na década de 1930. Significação-Revista de Cultura Audiovisual, v. 40, 2013.

GOMINHO, Zélia. Veneza Americana X Mucambópolis: O Estado Novo na Cidade do Recife (décadas de 30 e 40). Olinda: Livro Rápido, 2007.

GUNNING, Tom. O retrato do corpo humano: a fotografia, os detetives e os primórdios do cinema, In: CHARNEY, Leo; SCHWARTZ, Vanessa R. (Orgs.). O cinema e a invenção da vida moderna. São Paulo: Cosac \& Naify, 2004.

LEITE, Sidney Ferreira. Cinema Brasileiro: das origens à retomada. São Paulo: Editora Fundação Perseu Abrano, 2005.

MARTIN, Marcel. A linguagem cinematográfica. São Paulo: Brasiliense, 2005.

NÓVOA, Jorge Luiz Bezerra. Apologia da relação Cinema-História In: NÓVOA, Jorge; BARROS, José D'Assunção (org.). Cinema-História: teoria e representações sociais no cinema. Rio de Janeiro: Apicuri, 2012.

PANDOLFI, Dulce. Os anos 1930: as incertezas do regime. In: FERREIRA, Jorge; DELGADO, Lucilia de Almeida Neves (orgs.). O Brasil Republicano, 2 - O tempo do nacional-estatismo: do início da década de 1930 ao apogeu do Estado Novo. Rio de Janeiro: Civilização Brasileira, 2012.

REZENDE, Antonio Paulo. O Recife: história de uma cidade. Recife: Fundação de Cultura da Cidade do Recife, 2005. 
SIMIS, Anita. Estado e cinema no Brasil. São Paulo: Annablume; Fafesp; Itaú Cultural, 2008.

\section{Fontes consultadas:}

Jornal A Província (Recife). 1929-1933. Fundação Biblioteca Nacional / Hemeroteca Digital. Jornal do Recife (Recife). 1929-1930. Fundação Biblioteca Nacional / Hemeroteca Digital. Revista Pra Você (Recife). 1930-1933. Fundação Joaquim Nabuco. 